eral oversight of the procedure, but also spurred investigators to adopt more realistic goals and a greater awareness of the ethical issues involved. It "did make everyone here slow down and refocus," says Katherine High, a researcher at Children's Hospital of Philadelphia who is using the adeno-associated virus (AAV) as a vector to improve blood clotting in patients with hemophilia B. Moreover, researchers are now more aware of the need for convincing preclinical data, says another researcher who asked not to be identified, and as a result, research aims are now much more reasonable. "The major mistake, which became so clear [after] Jesse's death, was that scientists had promised too much too early," he says. Harvard neurologist Xandra Breakfield wouldn't use the word "recovery" to describe the changes brought about by the Gelsinger case. "Rather than recovering from it, I believe most scientists and physicians have taken it very much to heart and incorporated it into their mindset,' she says. "This painful experience has brought a sobriety and maturity to the field." Breakfield studies the genetics of inherited neurological diseases and

\title{
Compromise for Australian ES cell research
}

Australia has opted for a less liberal position than the UK on embryonic stem (ES) cell research regulation but less restricted than the US publicly-funded sector. Last month, Australian prime minister John Howard announced that surplus embryos from fertility treatments in existence as of 5 April can be used for research, but new ones cannot be created simply for medical science. Somatic-cell nuclear transfer, and therefore therapeutic cloning, is banned.

The announcement has received mixed reactions from the research community. "It's the best we probably were able to obtain under the political circumstances," says Alan

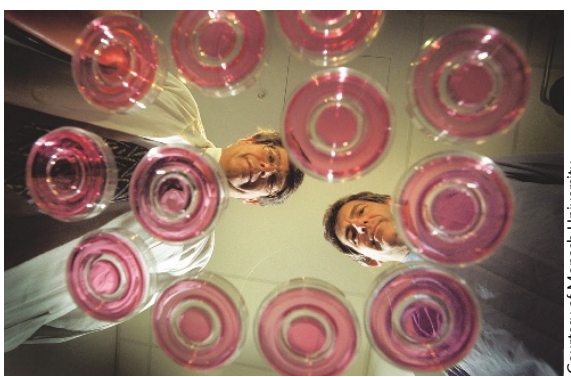

Trounson and Pera: ES cell visionaries which the agreement was reached-as 'illogical', and primarily a means to quell fears expressed by conservative politicians of 'embryo farming' for commercial purposes. The restriction will be reviewed in a year, and many researchers are confident that the ban will be lifted.

John Smeaton, president and chief executive of BresaGen, an Australian biotechnology company developing stem cell therapies, sees "no logic in a cut-off date" for embryos, saying, "We had hoped the Australian answer would have been more liberal and might have allowed us to repatriate some of our work." Smeaton argues that fresh embryos are superior to frozen embryos Trounson, direc-

tor of the Monash University Institute of Reproduction and Development.

Some applaud the national legislation, to be introduced next month, which will allow investigators unencumbered access to embryos and resolve the current 'patchwork' of legislation across the country. "We will be able to create stem cell lines in our own lab as soon as they change the laws," says Trounson, whose team currently imports stem cell lines from the Singapore-registered Australian company ES Cell International (ESI).

However, many researchers, including Trounson, view the decision to ban the use of embryos created after the arbitrary date of 5 April-the date on is looking into possible vectors to penetrate the nervous system.But although she admits that new emphasis on reporting adverse event is "critical to the success of this new technology," like many others Breakfield would now like to see the reporting process streamlined. One major sticking point on this level was resolved in March when the NIH's Recombinant DNA Advisory Committee (RAC) agreed to adopt the Food and Drug Administration (FDA) reporting program, allowing annual rather than real-time reporting of nontherapy-related adverse events.

Tinker Ready, Boston

Development at Monash University. Others express stronger views: "As a company interested in developing therapeutic cloning technology, we will be forced to move the human component of the research offshore," says Peter Mountford, chief executive of the biotechnology company Stem Cell Sciences, based in Melbourne, which has sought a less restrictive research environment through a collaborative program with Austin Smith's team at the Centre for Genome Research in Edinburgh.

"For Australia to turn its back on therapeutic cloning at this early stage is very short-sighted," agrees Smeaton, who expresses concerns that the country may end up importing downstream therapeutic developments in the technology in the future. Mountford describes the decision as a "step backwards from the recommendations of the parliamentary committee," referring to the 2-year government inquiry into cloning and stem cell research that ended in August 2001, but which had left a loophole for research in nuclear transfer technology.

The ban on creating embryos for purposes other than assisted reproduction applies to both publicly and privately sponsored research. It will be reviewed within 3 years, and many researchers see that as a time to launch a fresh bid to persuade political powers to relax the restriction. In the meantime, the challenge is to establish a means by which researchers will be able to access the estimated 70,000 surplus embryos in frozen storage. This responsibility falls to the National Health and Medical Research Council as the national regulatory and licensing body. Carina Dennis, Sydney 